\title{
Phytophthora Species Associated with Cranberry Root Rot and Surface Irrigation Water in New Jersey
}

\author{
Peter V. Oudemans, Rutgers University, Blueberry and Cranberry Research and Extension Center, Lake Oswego \\ Road, Chatsworth, New Jersey 08019
}

\begin{abstract}
Oudemans, P. V. 1999. Phytophthora species associated with cranberry root rot and surface irrigation water in New Jersey. Plant Dis. 83:251-258.

A lupine baiting technique was used to detect the presence of Phytophthora spp. in several streams, irrigation reservoirs, and drainage canals used in cranberry cultivation. P. cinnamomi was found to be widely distributed throughout the study area in the southern New Jersey Pinelands, and was present both upstream and downstream of agricultural activities. A second species, identified as $P$. megasperma, was more restricted in its distribution and was never isolated from a water system that did not also contain P. cinnamomi. In a survey of commercial cranberry production, $80 \%$ of the acreage represented (approximately $37 \%$ of total New Jersey production area) was exposed to one or both Phytophthora spp. through application of infested water from irrigation reservoirs. Based on the widespread distribution of $P$. cinnamomi, it is likely that this pathogen was introduced many years prior to its discovery on cranberry in the 1980 s, which corresponded to the adoption of overhead irrigation in the crop. There were slight differences between the two species in seasonal occurrence. The highest levels of $P$. cinnamomi were found during the summer months (July to August) whereas P. megasperma was highest during the spring (April to May) and fall (September to October) months.
\end{abstract}

Additional key words: bioassay, disease prediction, lupine baiting, Vaccinium macrocarpon

Root rot of cranberries (Vaccinium macrocarpon Aiton) is caused by several Phytophthora spp. $(1,2,11)$. The primary pathogen is P. cinnamomi and is found in the northeast cranberry growing regions, including Massachusetts and New Jersey, where it can cause significant crop losses (1). Other species of Phytophthora have been associated with a cranberry decline syndrome in Wisconsin (11); however, the importance of these other species in causing root rot remains questionable (5).

Cranberry root rot was first reported as a serious disease during the mid-1980s in Massachusetts (2). Myers (15) described a similar vine disease in New Jersey as early as 1983. Although the disease in New Jersey initially was attributed to plant pathogenic nematodes, evidence from field tests showed that treatment with nematicides failed to remedy the problem. The dieback described by Myers (15) was likely Phytophthora root rot and the association with nematodes may have been coincidental. Alternatively, a synergistic interaction with

Corresponding author: P. V. Oudemans;

E-mail address: oudemans@aesop.rutgers.edu

This work was supported by grants from the USDA-CSRS and Ocean Spray Cranberries, Inc.

Accepted for publication 14 November 1998.

Publication no. D-1998-1229-03R

(C) 1999 The American Phytopathological Society
Phytophthora spp. and nematode spp. may have been occurring, as has been described for other disease systems (6).

The first observations of cranberry root rot in New Jersey coincided with the introduction and use of overhead irrigation. The majority of commercial cranberry acreage currently is equipped with overhead irrigation to aid in prevention of frost damage and heat stress, as well as to provide sufficient water for optimum plant growth. The reservoirs that feed the irrigation systems rely primarily on surface water. $P$. cinnamomi is a soilborne fungus known to be disseminated in both natural and artificial surface water systems $(7,20)$; therefore, it is possible that this pathogen is also transported in surface waters supplying New Jersey cranberry beds.

The purpose of this study was to determine if surface water acts as a source of inoculum of Phytophthora spp. and to evaluate both the distribution and the seasonal variation of these inoculum levels in surface water by a lupine baiting technique.

\section{MATERIALS AND METHODS}

Study area. This study was conducted in Burlington County, where over $80 \%$ of commercial cranberry farming in New Jersey is undertaken. The commercial cranberry beds that were sampled all had a history of root rot. The streams and cranberry beds sampled were representative of different drainage systems in the area (Fig. 1). The sampling sites (sites 1 to 4 ) in- cluded cranberry beds in three commercial cranberry farms and in the Rutgers Blueberry and Cranberry Research and Extension Center (RBCREC), as well as tributaries of the Wading River, Oswego River, and Batsto River that flow east into the Atlantic Ocean (Fig. 1). In addition, commercial cranberry beds (site 5) situated along the Rancocas Stream, which flows west into the Delaware River, were sampled. Site 1 (Figs. 1 and 2) consisted of 32 cultivated hectares divided into 19 beds. Oswego lake ( $>40$ ha), located at the north end of the site, supplies water to a series of reservoirs surrounding the cultivated area. Site 2 (Fig. 1) included four cultivated hectares divided into 20 0.2-ha experimental cranberry beds at the RBCREC. Each cranberry bed at this site was connected to an upper reservoir via an independent inflow and to the lower reservoir with an independent outflow. The reservoir at site 2 was connected to site 1 via marshy wetlands approximately $800 \mathrm{~m}$ wide. Water for sites 1 and 2 originated in Oswego Lake and flowed into either the Oswego or Wading Rivers after exiting the cranberry beds. Site 4 (Fig. 1) was located near the headwaters of the Shoal Branch of the Wading River (a tributary of the West Branch of the Wading River) and consisted of 44 cultivated hectares divided among 23 beds. Site 3 (Fig. 1) was located about 2 miles downstream on the Shoal Branch and consisted of 51 cultivated hectares divided among 20 beds. Site 5 (Fig. 1) consisted of 28 ha divided among 17 cranberry beds. Each bed was connected to an upper and lower reservoir via independent inflows and outflows. With the exception of the RBCREC (see below), all sites received three annual applications of the fungicide metalaxyl $(2.0 \mathrm{~kg} / \mathrm{ha})$ to manage Phytophthora root rot (approximate dates of application were mid-April, mid-June, and early November).

A series of six 0.2-ha beds (three pairs) located at RBCREC (site 2) were used to assess the effect of metalaxyl treatments on inoculum levels in the drainage canals surrounding the beds. The inoculum levels in drainage canals were tested on a weekly basis using eight lupine baits per bed per week over a period of 19 weeks. One bed of each pair received a mid-season metalaxyl treatment on 24 July (7 pints of Ridomil 2EC/acre, Ciba-Giegy Corp., Greensboro, NC) and the other was left untreated. The resulting levels of lupine in- 
fection were subjected to an analysis of variance using each bed as the experimental unit, and a randomized complete block design was applied because three pairs of beds were examined.

Isolation of Phytophthora spp. from cranberry plants. To determine which
Phytophthora spp. were causing root rot in the study areas, cranberry beds displaying patches of dieback were identified (1). Symptomatic plants with roots attached were removed from the edge of the dieback areas. Tissues were washed with tap water to remove adhering soil particles and then rinsed with sterile distilled water. Shoots with attached roots were cut into $\approx 1-\mathrm{cm}$ pieces and plated on PARPH (pimaricin, $10 \mathrm{mg}$; ampicillin, $100 \mathrm{mg}$; rifampicin, 10 $\mathrm{mg}$; pentachloronitrobenzene, $50 \mathrm{mg}$; hymexazol, $50 \mathrm{mg}$; Difco corn meal agar, 15 g; and distilled water, 1 liter), a Phytoph-

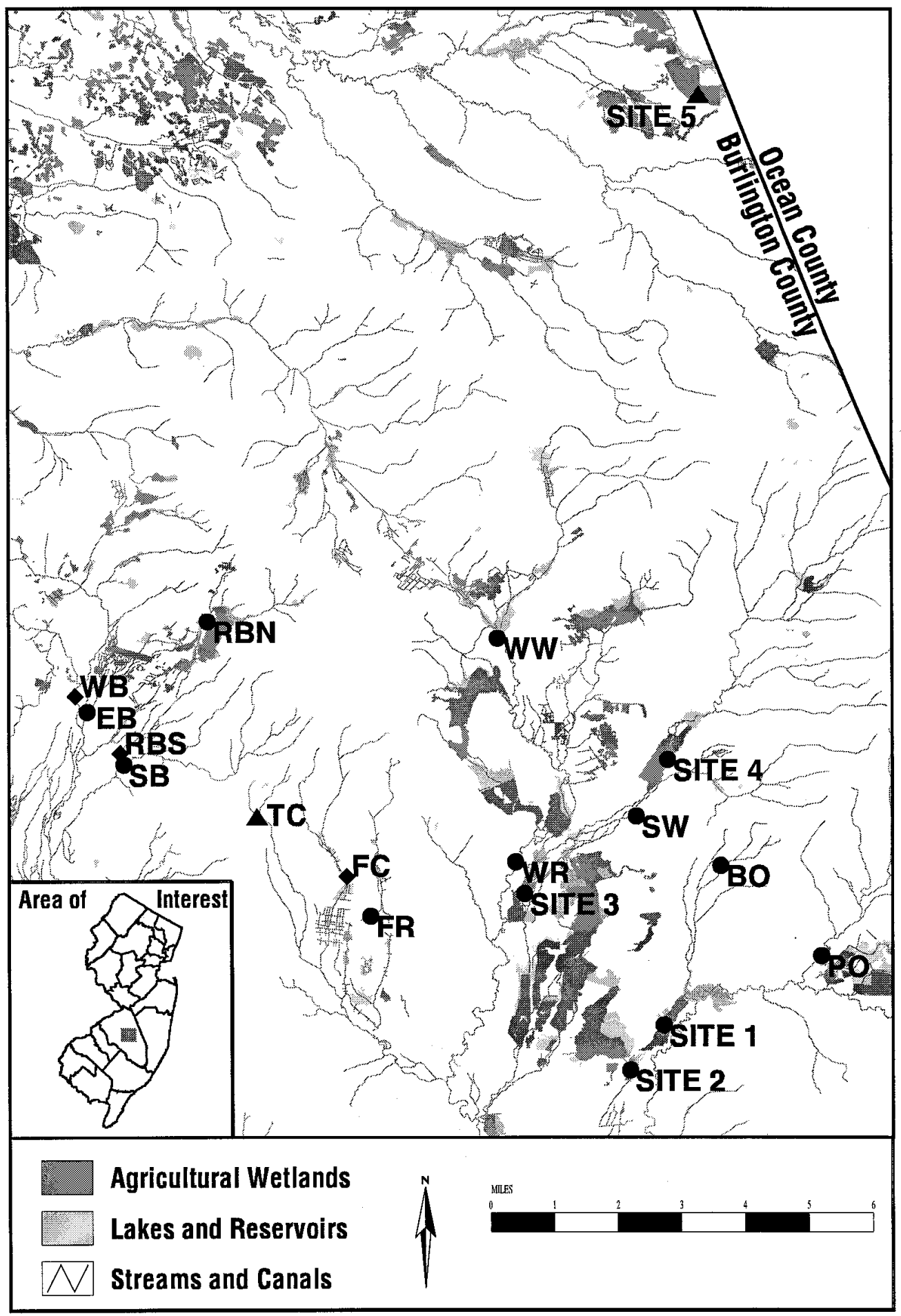

Fig. 1. Locations of sampling sites for the lupine baiting studies. Sites 1 to 5 are identified by numbers and stream sites are identified by a two- or threeletter code: $\mathrm{PO}=$ Papoose Branch, Oswego River; $\mathrm{BO}=$ Breeches Branch, Oswego River; SW = Shoal Branch, Wading River; WW = West Branch, Wading River; RBN = Roberts Branch, Batso River, north sampling site; RBS = Roberts Branch, Batso River, south sampling site; WB = West Batso River; EB = East Batso River; SB = Skit Branch, Batso River; TC $=$ Tulpehocken Creek; FC $=$ Featherbed Creek; FR = Friendship Reservoir; and WR $=$ Wading River. Circles represent locations where only Phytophthora cinnamomi was isolated, triangles represent locations where both $P$. cinnamomi and $P$. megasperma were isolated, and diamonds represent sites where no Phytophthora spp. were isolated. 
thora-selective medium $(12,19)$. Plates were observed for 10 days for the presence of mycelial growth, after which time, if no growth was visible, the test was considered negative. Any fungi growing from symptomatic tissue were transferred to clarified $20 \%$ V8-juice (V8C) agar (14) for identification.
Lupine baiting. Seedlings of 'Russells' blue lupines (Geo. W. Park Seed Co. Inc., Greenwood, SC) were grown from seed in sterile potting mix in the greenhouse for 10 to 15 days. For baiting, one seedling was secured in each $100-\mathrm{cm}^{2}$ Styrofoam boat with the roots extending 2.5 to $5.0 \mathrm{~cm}$ be-

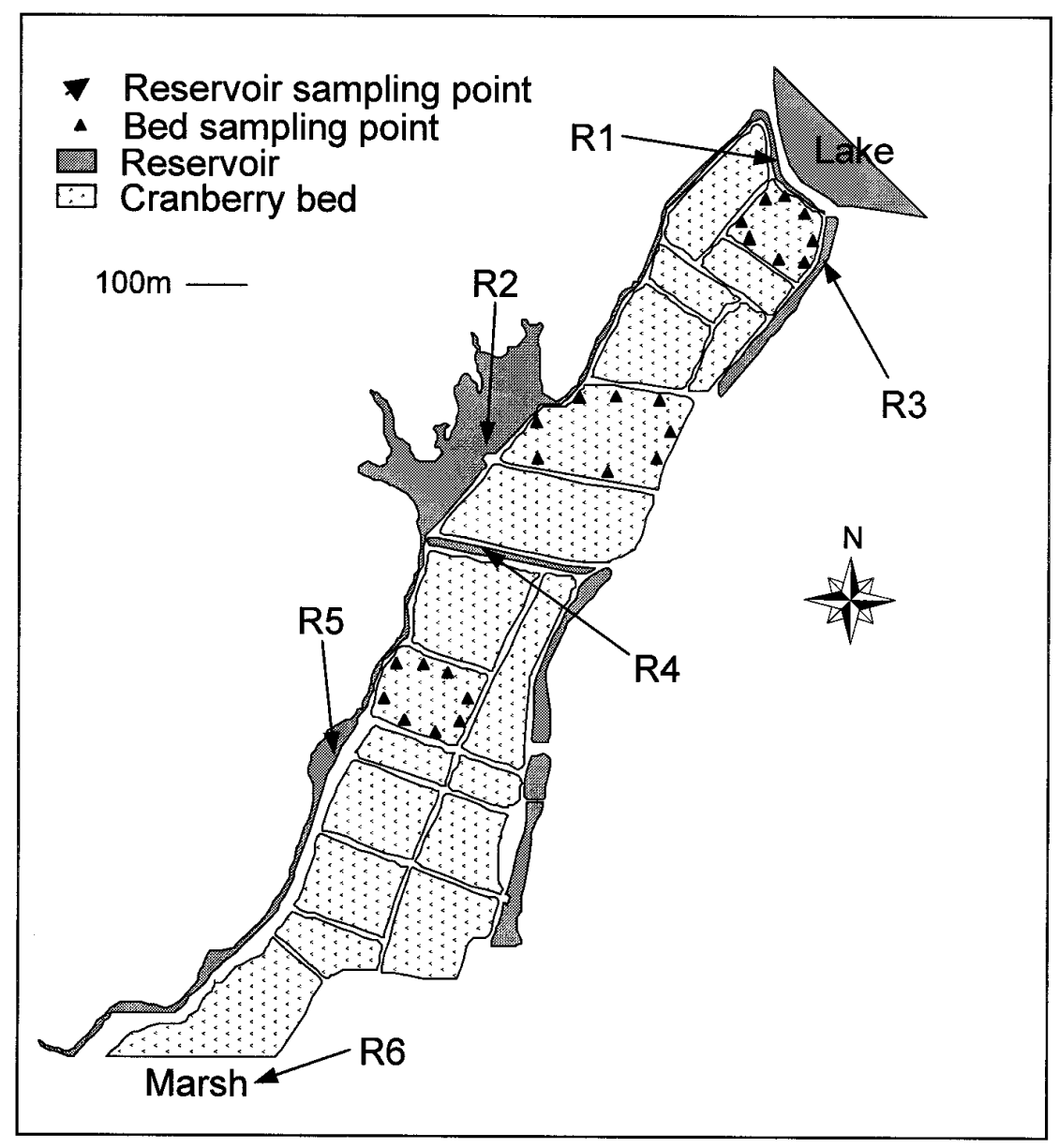

Fig. 2. Typical scheme for sampling a series of cranberry beds using lupine baits to test for the presence of Phytophthora spp. Reservoir sampling points refer to locations where four lupine baits were placed within $100 \mathrm{~m}$. Bed sampling points refer to locations of individual lupine baits placed in the drainage canals that surround each cranberry bed.

low the base. The boats were placed in streams, reservoirs, or drainage canals surrounding cranberry beds (Fig. 2). For streams or reservoirs, the boats were placed within a 100-m area along the bank. For drainage canals surrounding the cranberry beds, one or two boats were placed on each side of the bed (Fig. 2). The boats were held for $48 \mathrm{~h}$ in the location being sampled, then recovered and lupine seedlings removed. The roots were cut from the seedlings, washed with distilled water, and plated on PARPH. The plates were incubated for 2 to 4 days at $20^{\circ} \mathrm{C}$ or until mycelium was observed. If no mycelial growth occurred after 10 days, the test was considered negative. In early spring, this technique was very effective; however, as water temperatures increased during June and July, the number of contaminating fungi growing on the PARPH medium increased. The most problematic contaminant was one or more Mortierella spp. that had rapid growth rates and tended to obscure the growth of Phytophthora colonies. To improve selectivity, technical grade benomyl $(10 \mu \mathrm{g} / \mathrm{ml})$ was included in the antibiotic mixture for making the PARPH medium. This greatly reduced the growth rate of the Mortierella spp. contaminants and allowed Phytophthora spp. to grow (P. V. Oudemans, unpublished).

Sampling was conducted over a 3-year period at five sites (Table 1). In 1994, four boats were placed in drainage canals around each bed sampled and in each reservoir at every sampling date at sites 1, 3, and 4. In 1995 and 1996, eight boats were used in the drainage canals around each bed, and four were placed in each reservoir (Fig. 2). In 1995, eight boats were placed in reservoirs at site 1 from 9 January through 10 April, after which the largerscale sampling was initiated. Water temperatures were monitored in reservoirs and drainage canals using a temperature probe (Hanna Instruments Inc., Woonsocket, RI) mounted on a 2-m pole. Temperatures were taken at a 5- to $10-\mathrm{cm}$ depth.

Table 1. Summary of the numbers of lupine baits used and the recovery of Phytophthora spp. from sites 1 to 5

\begin{tabular}{|c|c|c|c|c|c|c|c|}
\hline \multirow[b]{2}{*}{ Location, year } & \multirow[b]{2}{*}{ No. samples ${ }^{\mathbf{a}}$} & \multicolumn{2}{|c|}{ Cranberry beds } & \multicolumn{2}{|c|}{ Reservoirs } & \multirow[b]{2}{*}{ Total baits $^{\text {b }}$} & \multirow[b]{2}{*}{ No. positive ( $\%$ positive) } \\
\hline & & No. beds & Baits/bed & No. reservoirs & Baits/reservoir & & \\
\hline Site 1,1994 & 27 & 1 & 4 & 1 & 4 & 216 & $50(23.1)$ \\
\hline $1995^{\mathrm{d}}$ & 14 & 0 & 0 & 2 & 4 & 112 & $0(0)$ \\
\hline 1995 & 27 & 3 & 8 & 6 & 4 & 1,296 & $497(38.3)$ \\
\hline Site 2,1995 & 17 & 6 & 8 & 0 & 0 & 816 & 487 (59.7) \\
\hline Site 3, 1994 & 27 & 2 & 4 & 0 & 0 & 216 & $58(26.9)$ \\
\hline 1995 & 24 & 2 & 8 & 2 & 4 & 648 & $247(38.1)$ \\
\hline Site 4, 1994 & 27 & 3 & 4 & 0 & 0 & 324 & $55(17.0)$ \\
\hline 1995 & 16 & 3 & 8 & 2 & 4 & 512 & $126(24.6)$ \\
\hline Site $5,1995^{\mathrm{e}}$ & 19 & 6 & 8 & 0 & 0 & 912 & $166(18.2)$ \\
\hline $1996^{\mathrm{e}}$ & 23 & 6 & 8 & 0 & 0 & 1,104 & $286(25.9)$ \\
\hline Total & $\ldots$ & $\ldots$ & $\ldots$ & $\ldots$ & $\ldots$ & 6,044 & $1949(32.2)$ \\
\hline
\end{tabular}

${ }^{a}$ Number of weekly samples.

b Total number of lupine baits used per year.

${ }^{\mathrm{c}}$ Total number of lupine baits infected with Phytophthora spp.

d This series of samples were taken during the period from 9 January to 10 April.

e Averages include values for two species, $P$. cinnamomi and $P$. megasperma. 
Table 2. Recovery of Phytophthora cinnamomi from lupine bait sampling of native streams tested in $1995^{\mathrm{a}}$

\begin{tabular}{llcccc}
\hline Code $^{\mathbf{b}}$ & \multicolumn{1}{c}{ Location } & 18 July & 15 August & 22 August & 18 September \\
\hline PO & Papoose Branch, Oswego River & $3 / 16$ & $0 / 16$ & $\mathrm{nt}^{\mathrm{c}}$ & $\mathrm{nt}$ \\
BO & Breeches Branch, Oswego River & $3 / 16$ & $0 / 16$ & $\mathrm{nt}$ & $\mathrm{nt}$ \\
SW & Shoal Branch, Wading River & $14 / 16$ & $16 / 16$ & $\mathrm{nt}$ & $\mathrm{nt}$ \\
WW & West Branch, Wading River & $\mathrm{nt}$ & $\mathrm{nt}$ & $2 / 8$ & $3 / 8$ \\
RBN $^{\mathrm{d}}$ & Roberts Branch, Batsto River, north & $\mathrm{nt}$ & $\mathrm{nt}$ & $4 / 8$ & $4 / 8$ \\
WB & West Batsto River & $\mathrm{nt}$ & $\mathrm{nt}$ & $0 / 8$ & $0 / 8$ \\
EB & East Batsto River & $\mathrm{nt}$ & $\mathrm{nt}$ & $5 / 8$ & $2 / 8$ \\
RBS & Roberts Branch, Batsto River, south & $\mathrm{nt}$ & $\mathrm{nt}$ & $0 / 8$ & $0 / 8$ \\
SB & Skit Branch, Batsto River & $\mathrm{nt}$ & $\mathrm{nt}$ & $2 / 8$ & $0 / 8$ \\
TC & Tulpehocken Creek & $\mathrm{nt}$ & $\mathrm{nt}$ & $0 / 8$ & $0 / 8$ \\
FC & Featherbed Creek & $\mathrm{nt}$ & $\mathrm{nt}$ & $0 / 8$ & $0 / 8$ \\
FR & Friendship Reservoir & $\mathrm{nt}$ & $\mathrm{nt}$ & $4 / 8$ & $4 / 8$ \\
WR & Wading River & $\mathrm{nt}$ & $\mathrm{nt}$ & $5 / 8$ & $7 / 8$ \\
\hline
\end{tabular}

a Values represent the number of lupine baits infected out of the total number placed in stream.

b This code is used for locations on the map in Figure 1.

c Not tested.

${ }^{\mathrm{d}} \mathrm{RBN}$ and RBS are the same stream with northern and southern sampling locations.

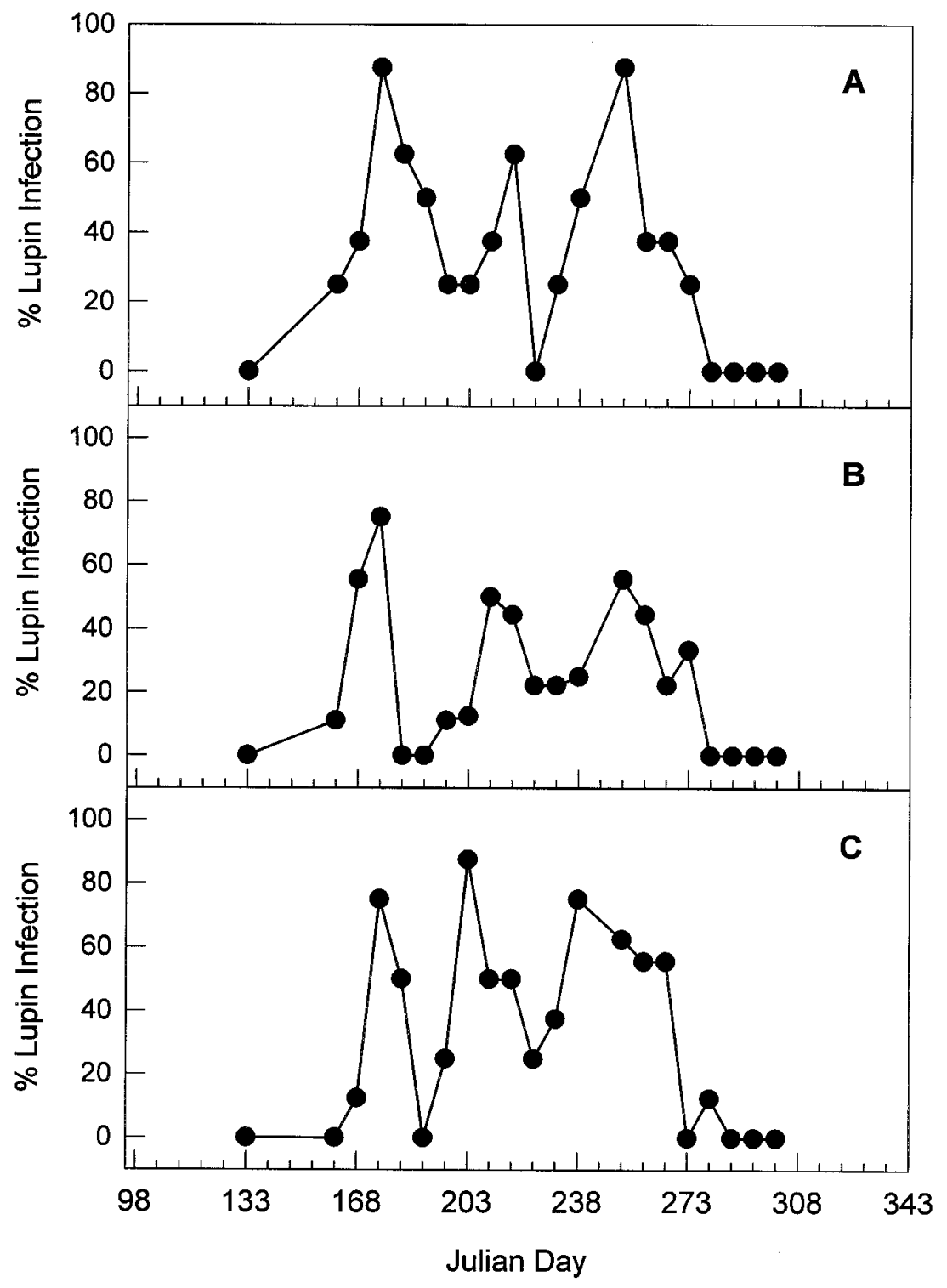

Fig. 3. Percentage of lupine traps infected with Phytophthora cinnamomi from drainage canals surrounding cranberry beds on three commercial cranberry farms in 1994 . Number of beds sampled and baits used are presented in Table 1. (A to C) Percentage of lupine baits infected with $P$. cinnamomi for sites 1, 3, and 4, respectively. Each sampling date (x-axis) refers to the beginning of a 2-day period when lupine baits were held in the drainage canals or reservoirs.
Sampling of streams was conducted to assess the distribution of Phytophthora spp. in the cranberry-growing region of New Jersey. Samples were taken on at least two separate dates from 13 stream locations (Table 2 and Fig. 1). Lupine baits ( $n=8$ to 16 ) were placed within a 100-m area along each stream. Reservoirs on six commercial cranberry farms not sampled previously (i.e., not sites 1 to 5) also were tested. In those cases, reservoirs and drainage canals were sampled using lupine baits as described for sites 1 to 5 (Fig. 2). The area of commercial cranberry beds supplied by these reservoirs was estimated to determine the approximate acreage exposed to Phytophthora spp. inoculum.

Identification of Phytophthora spp. All identifications were made using morphological characteristics. Cultivation of fungi for identification was performed at $20^{\circ} \mathrm{C}$ without light, unless otherwise stated. Colony morphology, mycelium morphology, and presence of oospores or chlamydospores were determined from direct observation of the cultures on V8C agar. Sporangia were produced by culturing mycelium for 2 days in the dark at $20^{\circ} \mathrm{C}$ in dilute $4 \%$ V8C broth, then replacing the broth with either stream water or a sterile mineral salts solution (3) and growing them for 3 to 5 days at $20^{\circ} \mathrm{C}$ in a lighted incubator. Isolates not belonging to the genus Phytophthora were discarded. Mating type was determined by mating unknowns with two standard isolates of $P$. cinnamomi (P2021-A1 from camellia and P2428-A2 from avocado were obtained from the Phytophthora-spp. collection, University of California, Riverside) on V8C agar plates. Comparisons among isolates were made using two diagnostic isozyme markers, malate dehydrogenase (MDH) and phosphoglucose isomerase (PGI), separated by cellulose acetate electrophoresis (16), with the two standard isolates listed above.

\section{RESULTS}

Isolation, identification, and characterization of Phytophthora isolates. Over 200 isolations were made in 1994 to 1995 from symptomatic cranberry root and runner tissue obtained from cranberry beds located within the study area. The isolates frequently yielded a Phytophthora sp. In cases where symptomatic vines were Phytophthora-free, the symptoms could be ascribed to either an insect infestation or infection by the fairy ring fungus, Psilocybe agrariella. All Phytophthora isolates from sites 1 to 4 were morphologically similar. Sporangia were non-papillate, internally proliferating, and measured between 65 and $105 \mu \mathrm{m}$ in length by 23 to 54 $\mu \mathrm{m}$ in breadth when produced according to Chen and Zentmyer (3). Oospores with amphigynous, predominantly unicellular antheridia were produced when mated with 
a known A1 isolate (P2021) but not the known A2 isolate (P2428). Chlamydospores were produced abundantly in both liquid and solid clarified V8 juice media. The mycelium was corraloid with numerous hyphal swellings. A subset of 20 isolates from these sites had identical isozyme patterns at two loci (MDH and PGI) with the standards P2428 and P2021. Based on comparisons with two known isolates of $P$. cinnamomi (P2021 and P2428), all of the isolates from diseased cranberry tissues in sites 1 to 4 and several isolates from site 5 were identified as $P$. cinnamomi. A second species was isolated from diseased tissues in site 5. Isolates of this species were homothallic and produced oospores with paragynous antheridia. Oogonia ranged from 22 to $40 \mu \mathrm{m}$ and oospores were aplerotic. Sporangia were non-papillate, internally proliferating, and measured 32.5 to $63 \mu \mathrm{m}$ in length by 22 to $38 \mu \mathrm{m}$ in width, with an average length:breadth ratio of 1:6. These morphological characteristics closely resemble published descriptions of $P$. megasperma $(7,10)$. In addition, all of the isolates tested had identical isozyme profiles (MDH and PGI) that were distinct from those of $P$. cinnamomi. Comparisons with other $P$. megasperma isolates was not undertaken because it is a complex species and many of subgroups within it may represent new species $(8,10)$. Therefore, these isolates are tentatively identified as $P$. megasperma.

Lupine baiting. Over 6,000 lupine baits were used during the period from 1994 to 1996. Of those, only $32 \%$ were infected (Table 1) by either of the Phytophthora spp. identified in this study, and rates of infection fluctuated from 0 to $100 \%$. In 1994, lupine baits were placed in drainage canals and reservoirs beginning on 1 May, approximately 30 days following removal of the winter flood. P. cinnamomi was first recovered from drainage canals on 17 May (Fig. 3). The frequency of isolation varied from 0 to $100 \%$ during the season (Fig. 3) and sampling ended on 31 October because no Phytophthora spp. had been recovered for at least three consecutive sampling periods. Cranberry beds were flooded during the winter months (December to April). Lupine baits placed in reservoirs and flooded beds at site 1 during the period from 9 January through 12 April 1995 did not yield any Phytophthora isolates (Table 1). During the growing season in 1995, the drainage canals and reservoirs at five sites were sampled on a regular schedule beginning 19 April and continuing until beds were flooded for harvest (Fig. 4). At site 5, two species were recovered (Fig. 5), as was the case for tissue isolations. The two species appeared to have different patterns of seasonal activity in 1995 and 1996 (Fig. 5). P. megasperma was isolated at higher frequencies in the spring and fall, while $P$. cinnamomi was isolated more frequently during the summer months.
Since the recovery of $P$. cinnamomi was highly variable throughout the season, a correlation analysis was conducted to determine if these fluctuations were repro- ducible. The results from the 1995 study (Fig. 4) indicate that lupine infection in canals was generally correlated with lupine infection in reservoirs for sites 1,3 , and 4

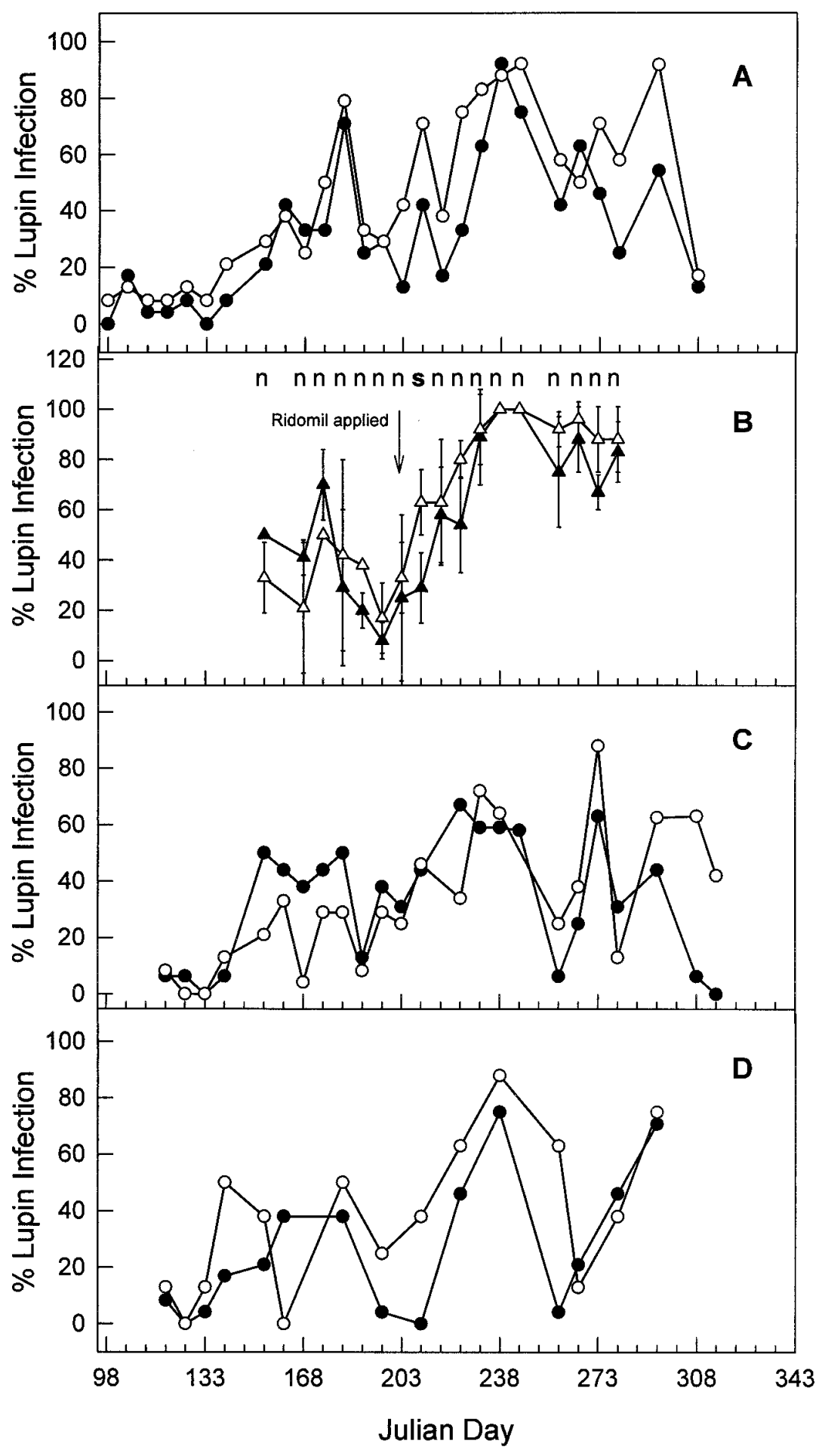

Fig. 4. Percentage of lupine traps infected with Phytophthora cinnamomi from drainage canals surrounding cranberry beds on three commercial cranberry farms in 1995. Numbers of beds and reservoirs sampled and baits used are presented in Table 1. (A to D) Percentage of lupine baits infected with P. cinnamomi for sites 1 to 4, respectively. Each sampling date (x-axis) refers to the beginning of a 2-day period when lupine baits were held in the drainage canals or reservoirs. Closed circles represent frequency of recovery from drainage canals and open circles represent recovery from reservoirs. Data presented for site 2 represent the average values of lupine infection from drainage canals surrounding three beds treated with metalaxyl on 24 July (Julian day 305; solid triangles) and three untreated beds (open triangles). Letters above each sampling date refer to significance (5\%). Nonsignificant differences are represented by "n" and significant differences by "s." 
(Table 2). The results also suggest that lupine infection was correlated among sites for both reservoirs and drainage canals. Site 2 was not included in the analysis because sampling was initiated later in the season, and site 5 was omitted because it was situated on a separate watershed from the other sites.

Regression analyses were conducted using CoStat (ver. 5.01; CoHort Software, Inc. Minneapolis, MN) to determine how water temperature influenced the amount of lupine infection. The first analysis was conducted using lupine infection data and water temperature data collected in 1995 from sites 1, 3, and 4. The data from each site was averaged and the analysis was conducted on the pooled data for the three sites for the period from 19 April (Julian day 109) through 3 July (Julian day 184) 1995. The average water temperature in beds and reservoirs ranged from 12 to $22^{\circ} \mathrm{C}$ and lupine infections ranged from 0 to $50 \%$. The results indicate a significant, positive relationship between water temperature and percent lupine infection by $P$. cinnamomi when a second-order quadratic model was used (Fig. 6A). The data from site 5 for 1995 (results not shown) exhibited a similar trend for P. cinnamomi; however, a negative relationship was seen for $P$. megasperma. The correlation coefficients for both species from site 5 in 1995 were low; presumably, this was due to the overall lower recovery rates. In the second analysis, the data for 1996 from site 5 was averaged and analyzed for the period from 8 April (Julian day 98) through 3 June (Julian day 154) 1996. The average water temperature in beds and reservoirs ranged from 11 to $23^{\circ} \mathrm{C}$ and lupine infections ranged from 0 to $48 \%$ for $P$. cinnamomi and 0 to $17 \%$ for $P$. megasperma. The results indicate that $P$. megasperma decreased with increasing water temperatures while P. cinnamomi increased (Fig. 6B). For $P$. cinnamomi, an inflection point between 16 to $18^{\circ} \mathrm{C}$ was seen in both analyses (Fig. 6A and B). Water temperatures ranged from 20 to $25^{\circ} \mathrm{C}$ during the summer months and did not correlate with lupine infection.

Effect of metalaxyl applications. The average recovery of $P$. cinnamomi using

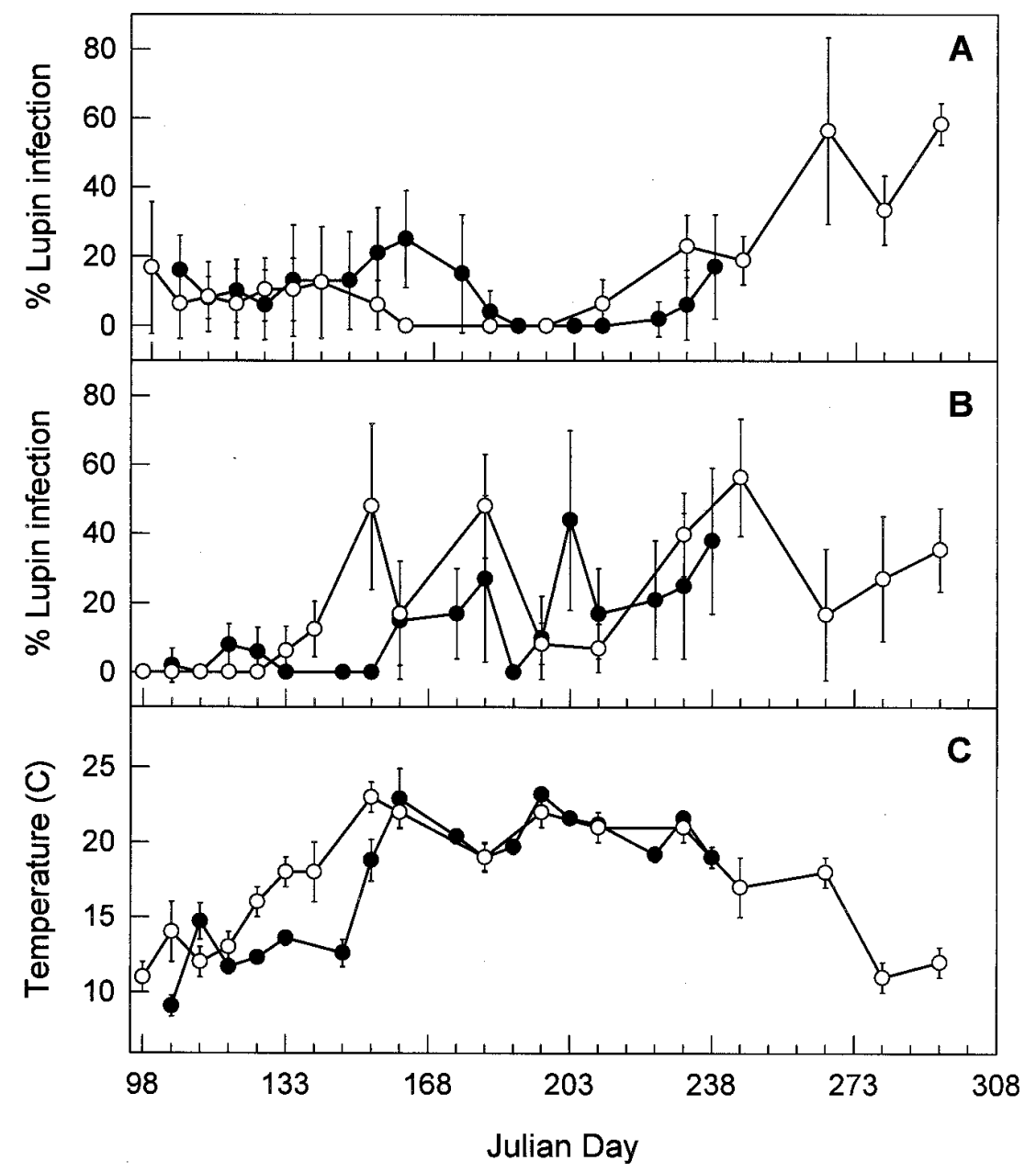

Fig. 5. Recovery of two species of Phytophthora with lupine baits and water temperatures for 1996 and 1996 from site 5. Values were calculated as averages from 6 cranberry beds; (A) P. megasperma; (B) P. cinnamomi. Each sampling date (x-axis) refers to the percentage of lupine bait infected during the 2-day period the bait was held in the drainage canal. (C) Water temperature measured at each sampling date. Closed circles represent data from 1995 and open circles represent data from 1996. lupine baits placed in drainage canals surrounding treated and untreated beds at the RBCREC showed very little effect of metalaxyl (Fig. 4B). In fact, no significant differences were found between the treated and untreated beds, with the exception of the sampling period immediately following the metalaxyl application (Fig 4B).

Survey. $P$. cinnamomi was recovered from lupine baits placed in streams both upstream and downstream of cultivated areas (Table 3 and Fig. 1). Detectable levels of inoculum were not present in four of the stream sampling locations (West Batso River; Roberts Branch, Batso River; Tulpehocken Creek; and Featherbed Creek). Three locations (Shoal Branch, Wading River; Roberts Branch, Batso River, North; and Wading River) consistently yielded over 50\% lupine infection, suggesting a higher level of inoculum.

The presence of Phytophthora root rot was tested by tissue plating at six additional farm sites. At those locations, lupine baits also were placed in reservoirs and drainage canals (number of reservoirs varied depending on location) for a minimum of three sampling dates. Inoculum was present in reservoirs and drainage canals of four of the six additional sites. This corresponded with the isolation of Phytophthora spp. from plant tissues at the same four sites. Both $P$. cinnamomi and $P$. megasperma were isolated from two of the sites and only $P$. cinnamomi was isolated from the other two sites.

Based on the sampling from all 11 farm sites, an estimate of the cultivated area exposed to Phytophthora spp. was made. This was done by determining the area of cultivated cranberry beds treated with irrigation water from the reservoirs that were tested. In total, 526 ha of cultivated cranberry beds or $37 \%$ of the total cultivated area in New Jersey were represented in the survey. Of these, 65\% (approximately 340 ha) was exposed to P. cinnamomi, $15 \%$ (approximately $80 \mathrm{ha}$ ) was exposed to both $P$. cinnamomi and $P$. megasperma, and 20\% (105 ha) did not have detectable levels of any Phytophthora spp. There were no locations where only $P$. megasperma was isolated.

\section{DISCUSSION}

Detection of Phytophthora spp. by baiting has been used extensively in assaying contaminated soils, water, and host tissue (7). Drilias and Jeffers (5) reported a bioassay procedure for Phytophthora spp. from cranberry soils. That procedure, like many others, involves recovering soil samples and conducting the bioassay elsewhere. The assay employed in this study was based on a method for isolating $P$. lateralis from streams (17) but has not been used extensively for detection of water supplies contaminated by Phytophthora spp. Kliejunas and Ko (13) also used lupine baiting to detect $P$. cinnamomi in 
Hawaiian streams and various other sources. Results obtained in this study confirm that field-based trapping can be a viable method for detecting Phytophthora spp. in surface water as well as monitoring for changes in relative inoculum levels. This also differs from previous studies (20) in which water samples were collected and then assayed. Lupine seedlings were an excellent bait plant because they could be produced from seed at any time during the year. This is in contrast with other types of bait, such as cranberry (5), pine needles, or pear fruit (7), that are not readily available throughout the year or may not be uniformly susceptible due to changes in tissue maturity.

Results presented in this study suggest that $P$. cinnamomi is a resident of the Pinelands region of New Jersey. Recovery of this species from water upstream of any current agricultural practices (Breeches Branch, Oswego River; Featherbed Creek; and Friendship Reservoir) indicates that it probably survives on native vegetation in the wetland areas that are sources for streams. Presently, there is no evidence that $P$. cinnamomi is causing any type of decline in these forested areas. Only the A2 mating type was found in this study. The A2 mating type is commonly found worldwide and occurs on a wide variety of host plant species, whereas the A1 mating type tends to be restricted both in host range and geographic distribution (22).

It is likely that $P$. cinnamomi was introduced to the northeastern region on another agricultural crop. P. cinnamomi was described in New Jersey in the 1930s on rhododendron (21) and later on blueberry (18). Crandall et al. (4) chronicled the history of $P$. cinnamomi on chestnut and chinkapin spp. in the southeastern United States. In that publication, evidence is presented which suggests that $P$. cinnamomi was present in container-grown plants as far north as Delaware and may have been present in North America since the beginning of the nineteenth century. It appears, based on the extensive distribution of $P$. cinnamomi, that this pathogen has been present in the New Jersey Pinelands for a significant period of time. Thus, it seems likely that the increase in cranberry root rot is the result of a shift in cultural practices (i.e., overhead irrigation) rather than a recent introduction.

P. megasperma has not been described previously from cranberry in New Jersey. Jeffers (11) described a similar species in Wisconsin, but comparison among the isolates has not been completed. Based on the morphology of the sporangia, oospores, and mycelium, this species falls easily within the published descriptions for $P$. megasperma $(7,10)$. However, P. megasperma is a taxonomically complex species $(8,9)$; therefore, further investigation is necessary to obtain an accurate identification to the subspecies level.
The distribution of $P$. megasperma was more restricted within the study areas than $P$. cinnamomi. All of the P. megasperma isolates came from two locations repre- senting two separate watersheds distinct from the Wading and Oswego Rivers watershed that includes sites 1 to 4 . Isolation of $P$. megasperma from lupine traps and

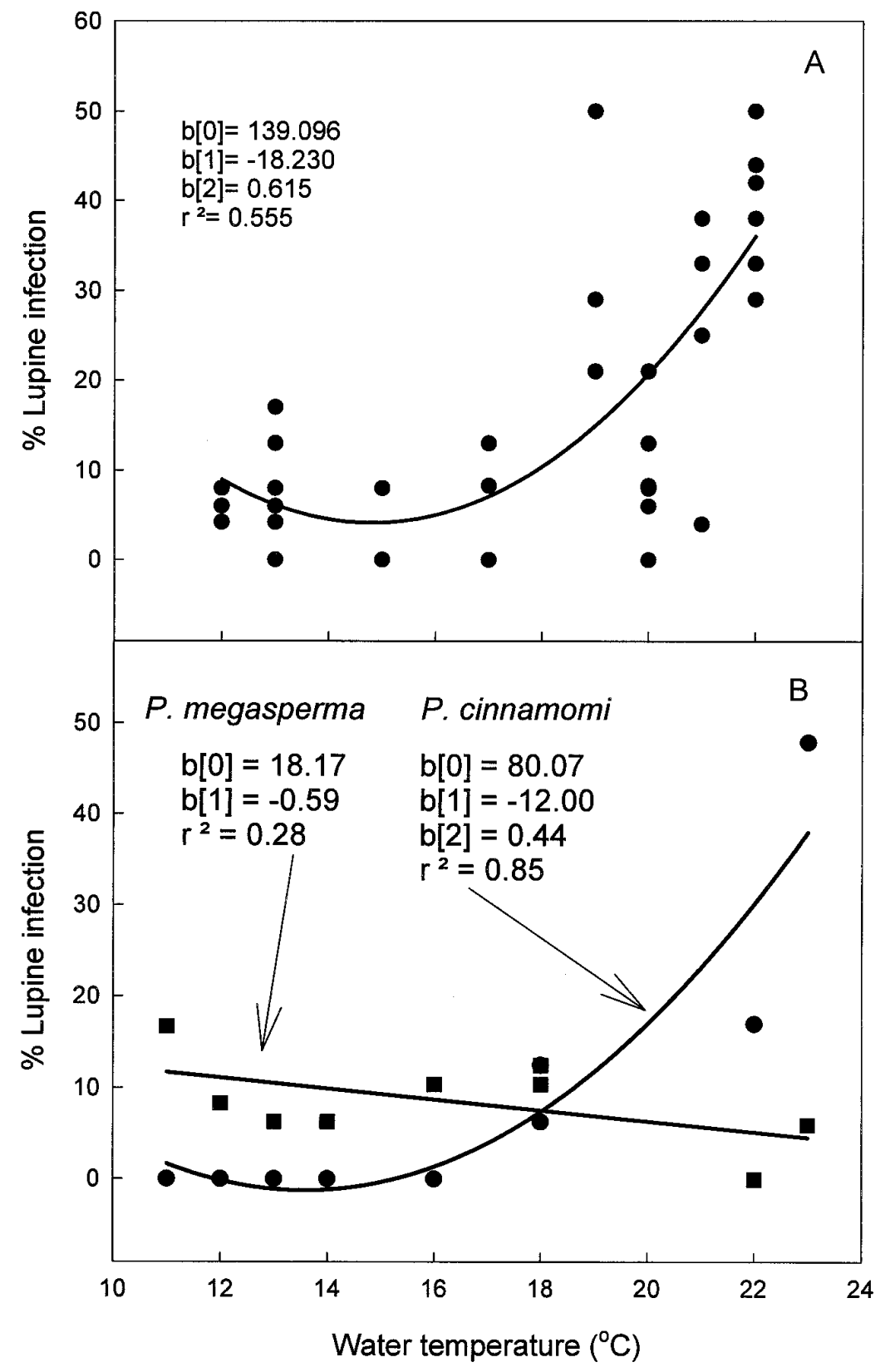

Fig. 6. Regression analysis of water temperature versus percent lupine infection by Phytophthora cinnamomi. and P. megasperma. (A) Data obtained from sites 1, 3, and 4 during 1995 for P. cinnamomi. (B) Data obtained from site 5 during 1996 for both P. cinnamomi (circles) and P. megasperma (squares).

Table 3. Results of tests for correlation between recovery of Phytophthora cinnamomi in lupine baits from reservoirs and canals located in sites 1,3 , and 4

\begin{tabular}{lccccc}
\hline Study site & $\begin{array}{c}\text { Site 1, } \\
\text { canal }\end{array}$ & $\begin{array}{c}\text { Site 1, } \\
\text { reservoir }\end{array}$ & Site 3, canal & $\begin{array}{c}\text { Site 3, } \\
\text { reservoir }\end{array}$ & $\begin{array}{c}\text { Site 4, } \\
\text { canal }\end{array}$ \\
\hline Site 1, reservoir & $0.85^{\text {a }}$ & $\ldots$ & $\ldots$ & $\ldots$ & $\ldots$ \\
Site 3, canal & 0.68 & 0.72 & $\ldots$ & $\ldots$ & $\ldots$ \\
Site 3, reservoir & 0.56 & 0.77 & 0.65 & $\ldots$ & $\ldots$ \\
Site 4, canal & 0.63 & 0.72 & 0.67 & 0.47 & $\ldots$ \\
Site 4, reservoir & 0.84 & 0.88 & 0.75 & 0.65 & 0.72 \\
\hline
\end{tabular}

${ }^{a}$ Correlation coefficients (r). 
root tissues was limited to the spring and fall. This species may not be detectable during the summer months if it is sensitive to higher temperatures that occur during that period.

Despite the presence of Phytophthora spp. in most irrigation reservoirs and drainage canals, there was a comparatively low level of root rot symptoms observed. The occurrence of severe symptoms generally was associated with poor soil drainage. Thus, the presence of inoculum alone appears to be insufficient to cause symptoms. Drilias and Jeffers (5) reported that flooding was not necessary for symptom expression in greenhouse tests with $P$. cinnamomi. However, other species did not reduce growth of cranberry plants unless flooding treatments were included. During the spring of 1996, large areas of dieback were observed in some cranberry beds, and, although not associated with poor drainage, did yield $P$. cinnamomi upon isolation. This unique situation was probably related to drought conditions experienced the previous season that might have enhanced symptom expression. It is not known how much of an impact chronic infection by Phytophthora spp. has on cranberry yields. With the widespread presence of inoculum in irrigation water, it is possible that a reduction in root mass though sublethal infections is reducing yields. Further work is necessary to assess this possibility.

Within the study area, $P$. cinnamomi was present in reservoirs and drainage canals for at least 6 to 7 months of the year and was found at most sampling sites. Inoculum levels in reservoirs correlated well with the levels found in drainage canals surrounding the beds, suggesting that the fluctuations in recovery were due to environmental factors rather than random variation. The recovery of $P$. cinnamomi during the early part of the season was positively correlated with water temperatures. In the case of $P$. megasperma, a different pattern was found. Inoculum levels were higher during the early and late parts of the season and were negatively correlated with water temperature. These data generally fit with the reported effects of temperature on sporangium development (7); however, more research is required to characterize the sporulation patterns for these two species. The causes of fluctua- tions in detection during the growing season are not known. The timing of the drops in recovery did not correspond with fungicide applications for either fruit rot or root rot and the water temperatures remained relatively constant during the summer months. Changes in the water volumes present in the drainage systems may have an effect on recovery, especially through dilution of inoculum because of rainfall. The application of metalaxyl did not have a significant, long-term effect on the recovery of $P$. cinnamomi from drainage canals. This is probably because inoculum in the canals does not originate only from the cranberry beds but also originates from the reservoirs and flows through the canals.

Lupine baiting has proven to be a useful method for monitoring the presence of inoculum of two species of Phytophthora in surface water. Although labor intensive, this approach provided valuable information on the distribution and seasonal fluctuations of Phytophthora spp. In this study, sites were identified where Phytophthora spp. were not detectable in irrigation water and also pointed to changes in recovery rates from irrigation water during the season. Thus, these data provide a basis to better assess if and when fungicide applications should be made. For example, fungicide applications to control $P$. cinnamomi made in early spring can be delayed until detectable levels of inoculum are found, and applications made at the end of the season can be deleted if they are not made until after inoculum levels have declined. Further work is necessary to quantify the relationship between water temperature and inoculum level before a useful predictive scheme can be developed.

\section{ACKNOWLEDGMENTS}

I thank G. Crawford and L. Breschia for technical assistance; and T. Spies and M. Hughes from the Grant F. Walton Center for Spatial Analysis and Remote Sensing, Rutgers University, for Figure 1.

\section{LITERATURE CITED}

1. Caruso, F. L., and Ramsdell, D. C., eds. 1995. Compendium of Blueberry and Cranberry Diseases. APS Press, St. Paul, MN.

2. Caruso, F. L., and Wilcox, W. F. 1990. Phytophthora cinnamomi as a cause of root rot and dieback of cranberry in Massachusetts. Plant Dis. 74:664-667.

3. Chen, D.-W., and Zentmyer, G. A. 1970. Production of sporangia by Phytophthora cinnamomi in axenic culture. Mycologia
62:397-402.

4. Crandall, B. S., Gravatt, G. F., and Ryan, M. M. 1945. Root disease of Castanea species and some coniferous and broadleaf nursery stocks, caused by Phytophthora cinnamomi. Phytopathology 35:162-180.

5. Drilias, M. J., and Jeffers, S. N. 1990. Detection of Phytophthora species in cranberry field soils. Phytopathology 80:1025.

6. Dropkin, V. H. 1980. Introduction to Plant Nematology. John Wiley \& Sons, Inc., New York.

7. Erwin, D. C., and Ribero, O. K. 1996. Phytophthora Diseases Worldwide. American Phytopathological Society, St. Paul, MN.

8. Förster, H., and Coffey, M. D. 1993. Molecular taxonomy of Phytophthora megasperma based on mitochondrial and nuclear DNA polymorphisms. Mycol. Res. 97:1101-1112.

9. Hansen, E. M., Brasier, C. M., Shaw, D. S. and Hamm, P. B. 1986. The taxonomic structure of Phytophthora megasperma: evidence for emerging biological species groups. Trans. Br. Mycol. Soc. 87:557-573.

10. Hansen, E. M., and Maxwell, D. P. 1991 Species of the Phytophthora megasperma complex. Mycologia 83:376-381.

11. Jeffers, S. N. 1988. Phytophthora species associated with a cranberry decline syndrome in Wisconsin. Phytopathology 78:1572.

12. Kannwischer, M. E., and Mitchell, D. J. 1981. Relationships of numbers of spores of Phytophthora parasitica var. nicotianae to infection and mortality of tobacco. Phytopathology 71:69-73.

13. Kliejunas, J. T., and Ko, W. H. 1976. Dispersal of Phytophthora cinnamomi on the island of Hawaii. Phytopathology 66:457-460.

14. Miller, P. M. 1955. V-8 juice agar as a general purpose medium for fungi and bacteria. Phytopathology 45:461-462.

15. Myers, R. F. 1991. Nematodes associated with dieback disease of cranberries. J. Nematol. (Suppl.) 23:629-633.

16. Oudemans, P., and Coffey, M. D. 1991 Isozyme comparison within and among worldwide sources of three morphologically distinct species of Phytophthora. Mycol. Res. 95:19-30.

17. Ribero, O. K. 1978. A Source Book of the Genus Phytophthora. Cramer, Vaduz, Liechtenstein.

18. Royle, D. J., and Hickman, C. J. 1963. Phytophthora cinnamomi on highbush blueberry. Plant Dis. Rep. 47:266-268.

19. Tsao, P. H., and Ocana, G. 1969. Selective isolation of species of Phytophthora from natural soils on an improved antibiotic medium. Nature 223:636-638.

20. Von Broembsen, S. 1984. Distribution of Phytophthora cinnamomi in rivers of the south-western cape province. Phytophylactica 16:227-229.

21. White, R. P. 1930. Two Phytophthora diseases of Rhododendron. Phytopathology 21:131.

22. Zentmyer, G. A., and Guillemet, F. B. 1981. Evidence for strains of Phytophthora cinnamomi. Plant Dis. 65:475-477. 